\title{
An investigation into the ways in which art is taught in an English Waldorf Steiner school
}

\section{Abstract}

Children who are educated using a Waldorf Steiner approach demonstrate superior expressive drawing skills (Rose, Jolley \& Charman, 2011) but little is known about how art is taught within this educational system. Four Waldorf Steiner primary school teachers participated in semi-structured interviews designed to explore the Waldorf Steiner educational philosophy, their training and the ways in which they approach art in the classroom. A social constructionist thematic analysis identified two themes - teacher's experience of art and the teacher and child's approach to art. Within these themes the importance of adequate training which stresses the value of art and gives teachers opportunity to engage in art activities was emphasised. Such training was linked to an effective teaching approach which placed importance on teaching skills and encouraging children to develop their understanding of art through discussion.

Keywords: art education, Waldorf Steiner schools, qualitative methods 


\section{Introduction}

There is a general consensus amongst academics and educators that art is an important subject which offers multiple benefits to children such as facilitating confidence and feelings of self-worth, creativity and imagination, a positive disposition towards learning and developments in motor control, language and literacy (Davis, 2005; Vygotsky, 1978; Yagamata, 1997). By enhancing children's ability to observe, communicate and be creative through art children can be equipped with the vital skills needed to express themselves (Hetland \& Winner, 2004). With the knowledge that adult art is vital to express moods, feelings and ideas (Jolley, 2010) it is essential that children's expressive art skills are developed to aid their imaginative and expressive thinking (Burkitt, Jolley \& Rose, 2010). Given the importance art has for children and adults the suggestion that the development of expression in children's drawings declines during the primary school years (Davis, 1997; Jolley, Fenn \& Jones, 2004) and that interest in art declines with age because children feel less positive about the activity as they get older (Burkitt et al, 2010) is a cause for concern.

Although parental input and the child themselves have an impact on how well children develop good artistic skills and a healthy relationship with their own ability in art, the way schools approach art education has been found to be vital in forming a child's expressive drawing skills (Burkitt et al, 2010). Indeed, Davis (1997) and Jolley et al. (2004) suggested that educational factors could explain the dip in expressive development they identified. Research conducted in an English context has given some insight into 
educational practices which could shape children's artistic development. Hallam, Lee and Das Gupta (2007) reported that the English national curriculum presents three different teaching positions - facilitator (which emphasises freedom and self-expression), philosopher (which focuses on art history and appreciation) and expert (which prioritises a directive approach and a focus on skills). Within the National Curriculum (Department for Education, 2013) each of these teaching positions is given equal weight and this suggests that teachers must develop an approach that gives children the chance to develop skills, have free expression and develop their aesthetic sensibilities. However, the lack of curriculum guidance on how to adopt a balanced teaching approach can be an issue because many primary school teachers are non-specialists who have received limited exposure to art in their teacher training (Clement, 1994) and have little confidence in their own skills as artists (O'Connor, 2000).

Interviews conducted with English primary school teachers highlighted dissatisfaction with their curriculum and a gap between educational policy and practice (Hallam, Das Gupta \& Lee, 2008). Teachers suggested that they adopt the position of expert or facilitator during art lessons and this was further supported with classroom based observational research (Hallam Das Gupta \& Lee, 2011; Hallam; Lee \& Das Gupta, 2011). The gap between policy and practice is an issue because children do not receive a consistent and balanced approach to art. Children are primarily encouraged to focus on skills or free expression and their opportunities to develop their understanding of art appreciation are extremely limited. Furthermore, when 
evaluating child art teachers demonstrated a preference for photo-realistic art over abstract or expressive art and this promotes a message that to be successful at art, children must closely follow instruction and create photorealistic art without free expression (Hallam, Lee \& Das Gupta, 2012). Although empirical research suggests that adults in general show a significance preference for realistic images (Vessel \& Rubin, 2010) it could be argued that one role of art education is to challenge this bias and to increase the understanding and appreciation of a diverse range of artworks (Parsons, 1987; Leder, Belke, Oeberst, \& Augustin 2004).

Research which has examined the ways in which art is taught in English National Curriculum schools suggests that educational practices within this education system could be detrimental to children's creative and expressive development (Jolley, et al, 2004). However, it is important to remember that not all children are educated within the state system and alternative educational approaches are growing in popularity (Sobo, 2014). Within the UK there are a number of Waldorf Steiner schools which are informed by their own specific educational philosophy.

In the UK, Waldorf Steiner schools are mainly independent nondenominational private schools. Recently three have been granted statefunding and run as academies (Steiner Waldorf Schools Fellowship, 2014). Waldorf Steiner teachers aim to educate children to meet them at their developmental stage according to the philosophy of Austrian scientist Rudolf Steiner (1861-1925). Due to this philosophy the arts are an important 
aspect to education because children are not seen as cognitively orientated individuals. It is suggested that children require combined nourishment of head, heart and hands to be educated as a whole person and develop as valuable members of society (Barnes, 1991). Within the Waldorf Steiner movement art is depicted as "the start of a long journey over eight years that gradually acquaints children with the pictorial resources, aiming to develop artistic skills and abilities for self-expression" (Wildgruber, 2012, p.96). Art is regarded as crucial to the harmonious development of the child's inner life (Nicol, 2011) and the entire curriculum is described as artistic-imaginative, with the dramatic and creative facets of art incorporated into the teaching of other subjects, including mathematics and the sciences (Lim, 2004). Artistic striving is encouraged in staff as well as pupils (Nicol, 2011) with Woods, Ashley and Woods (2005) reporting that 95\% of teachers from fifteen Waldorf Steiner schools in Britain believed that one characteristic of most teachers was superior artistic and creative skill.

Research has demonstrated that the educational system a child is exposed to plays a key role in shaping their artistic development (Cherney, Seiwert, Dickey, \& Flichtbeil, 2006). Findings consistently report that children educated at Waldorf Steiner schools have superior expressive drawing skills and creative ability when compared to children educated in National Curriculum and Montessori schools (Ogletree, 2000; Cox \& Rowlands, 2000; Kirkham \& Kidd, 2015). More recently, Rose, Jolley and Charman (2011) tested the expressive and representational drawing development of 135 children; 45 from each type of school, in three different age groups (5 -, 7- 
and 9). Within the study children were asked to complete three expressive drawings (that gave them freedom to draw anything that depicted the moods angry, happy and sad) and three representational drawings (observational drawings of a wooden mannequin, a house from memory and a free drawing). Analysis of the drawings revealed that those completed by Waldorf Steiner children were of higher expressive quality with more content themes and an increased use of formal artistic properties such as line and composition. Representational drawing was comparable among the schools, which shows that the expressive drawing skills of children within the Waldorf Steiner environment are not at the detriment of the ability to draw realistically.

The experimental research outlined above suggests that educational values have an integral role in shaping children's artistic development and have highlighted key differences in ability between different educational approaches. However, the methods utilised in this research did not explore the wider educational context and so little is known about the approach adopted by Waldorf Steiner teachers and how this approach facilitates superior expressive and creative artistic skills. The current paper addresses this by using qualitative methods to explore how Waldorf Steiner teachers conceptualise their approaches to art and how the Waldorf Steiner philosophy informs their teaching practice. This will enable an investigation of how these teaching differences may differ from practices adopted within the National Curriculum and provide the basis for future, observational 
studies which Jolley (2010) argued are essential for a more thorough understanding of art teaching approaches.

\section{Methodology}

In line with the small sample size required for qualitative research semistructured interviews were conducted with four teachers from a Waldorf Steiner Academy in the United Kingdom. The academy status of the school means that teachers are able to stay true to the beliefs of education as outlined by Rudolf Steiner but are inspected every four years by Ofsted (the office for standards in education, children's services and skills) to ensure that curriculum requirements outlined by the government are met.

All of the teachers interviewed undertook training that is as laid out by the Steiner Fellowship Code of Practice as part of the professional accreditation of Steiner teachers (Steiner Waldorf Fellowship, 2014). Such training varies in method of delivery but is reported to involve a "substantial component of artistic work" (Nicol \& Taplin, 2012: 97) guided towards both the teachers own artistic development and the acquisition of pedagogical skills. Training involves on-going, weekly practice in the arts (Edmunds, 2004) but also emphasises that artistic skills may be shown in different ways (e.g., through storytelling; Nicol, 2011). After completing their training, Waldorf Steiner teachers will engage in continued professional development in the arts, through attendance at teacher conferences and arts based activities in most staff meetings (Nichol \& Taplin, 2012). 
The teaching experience of the participants in the current study centred on Key Stage 1 (5-7 years old) and Key Stage 2 (7-11 years old), periods during which Waldorf Steiner education focuses upon the prioritization of the imagination and learning through experience and feeling (Woods et al. 2005). These Key Stages were focused on as Rose et al. (2011) suggested that Waldorf Steiner children in these age groups had superior expressive and creative drawing skills. Due to the practice of Waldorf Steiner teachers staying with the same class (usually from class one to eight) three of the teachers were able to reflect on the development of artistic skills throughout Key Stage 1 and Key Stage 2 to give a complete overview of the way art is taught within these key stages. One of the teachers only had experience of teaching key Stage 1. The experience of the teachers ranged from 12 to 20 years and at the time of the interview the teachers were aged between 41 and 52 . All the teachers were female and no attempt was made to interview teachers with a special gift for art.

Teachers were recruited via an email sent by the second author which provided information about the research and an informed consent form. The second author liaised with teachers who expressed interest in participating in the study and organised a convenient time for the interview to take place. The second author then led semi-structured interviews with the teachers in a staff meeting room at the school. The interview schedule invited the teachers to discuss their relevant training, the school's view of art education, the national curriculum and its place within the Waldorf 
Steiner curriculum for art, how art is taught within a school day and how it is assessed.

\section{Analytic approach and procedure}

The interviews were analysed using thematic analysis (Braun \& Clarke, 2006). In line with this approach themes that give insight into how art is taught within a Waldorf Steiner environment, what philosophies/influences shape how teachers approach art and how teachers view their own art skills were identified in the data set. As there is little research available on the way Waldorf Steiner teachers approach art education this analysis was conducted using an inductive approach. This approach is classed as data driven because it involves analysing the interviews without a pre-conceived hypothesis in mind (Frith \& Gleeson, 2004). Although researchers will to some extent be influenced by their wider knowledge of the topic they are researching an inductive approach involves a concerted effort to explore findings evident in the data set itself. As such the researcher opens themselves up to the possibility of finding unexpected content within the data set. Therefore, the themes presented in the analysis (and the focus of the paper) are driven more by the teachers themselves rather than a specific research agenda.

The six stages of thematic analysis outlined by Braun and Clark (2006) were used systematically to identify themes and patterns present in the whole data set. This involved the second author reading through the data set a number of times to generate a list of codes that were sorted in to themes 
and subthemes using mind maps. The first and second authors then established the validity of the themes by referencing them back to evidence within the interviews. At this point two major themes were identified: i) Teachers' experiences of art and ii) Teacher and children's approach to art. Data extracts which best represented these themes and their related subthemes were analysed by the first and second authors and this analysis was verified by the third author. It is important to note that the following analysis is informed by social constructionist framework in which language is not seen as a reflection of a person's thoughts or inner state (Burr, 1995). Instead, analysis focuses on exploring how language is used by the teachers to construct their experiences of teaching art and the Waldorf Steiner philosophy.

\section{Reflexivity}

Researchers cannot adopt "a value free, neutral, uninvolved approach" (Mies 1993, p. 67) and it is important to explore the roles the authors had in shaping the research process (Toerien, 2004). Each of the authors had differing levels of involvement with the Waldorf Steiner education system and this enabled them to bring different perspectives to the project. The second author works as a teaching assistant at the school involved in the research. This position afforded her 'insider status' (Vail, 1991). The existing relationship she shared with the teachers she interviewed facilitated the flow of the interviews as there was an existing rapport. There was an existing bond of trust and the teachers could be confident that they would not be "exploited, misrepresented or upset in some way" (Pitman, 2002, p. 
285). The first and third authors are academics who have an interest and knowledge of alternative educational systems but have no practical teaching experience. This 'outsider' status enabled them to approach the analysis with a level of naivety and critical insight that may not be accessible to an 'insider' (Lee, 2002).

\section{Analysis}

The two main themes identified - teacher's experiences of art and teacher and children's approach to art are examined in turn.

\section{Teacher's experiences of art}

Within the interviews the teachers spoke positively about the training they received and their personal experiences with art. This section of the analysis first explores the Waldorf Steiner approach to teacher training and how this prepares teachers to effectively deliver art lessons. It then goes on to examine how teachers spoke about their personal connection with art and the possible implications this has for teaching.

\section{Training}

"It's not, you know, there's only one way, sort of, to teach painting and drawing, you know, from their perspective. And, you know, you don't, it doesn't take years in which to do that whereas other things, well, you know - it seemed like that to me (laughs) - you know, but here we sort of say, no, 
you don't teach it like that: the obvious way. Or the way that everybody would learn because actually it's more than that because you're developing a relationship with colour." 'Jane' Jane had experience and training in National Curriculum and Waldorf Steiner approaches. In this quote she compares the two approaches and draws out key differences. At the start of the quote the National Curriculum training is presented as an approach which promotes "only one way". This positions the National Curriculum as a prescriptive regime which limits teacher's freedom by enforcing a one size fits all approach. Jane's suggestion that "It doesn't take years to do that" indicates that the National Curriculum approach can be learned quickly. This implies that (i) little time and effort is put into training and (ii) art has limited importance within the National Curriculum. As such National Curriculum training is presented as something that limits teacher's opportunity and ability to engage with art in a meaningful way. In contrast, Waldorf Steiner training is positioned as an approach which rejects "the obvious" and encourages teachers to develop "a relationship with colour" in a way that fosters the appreciation of aesthetic properties of individual artworks. This emphasis on developing a deep connection with art is noteworthy as it construes art as a subject which has personal meaning. Within Waldorf Steiner training art is conceptualised as more than just learning to paint and draw, it is a subject which offers the possibility for personal growth. 
Throughout the quote use of "their" and "here we" emphasises the divide between National

Curriculum and Waldorf Steiner training and firmly positions the teacher as someone who embraces the Waldorf Steiner approach. Repeated use of the phrase "you know" invites the interviewer to validate and agree with what has been said. This presents the divide between National Curriculum and Waldorf Steiner approaches and the positioning of the Waldorf Steiner approach as being the 'right way' to approach art as something that is widely accepted and taken for granted by others.

"The Steiner training we did, we had art pretty much every single week for two years and we also went and had weekends as well. And we went through the curriculum and we painted and drew and yeah there was a lot". 'Jessica'

Jessica explores her Waldorf Steiner training to validate its effectiveness. Jessica's suggestion that "we had art pretty much every single week for two years" emphasises the frequency of art during her training and this stresses the centrality of art within the Waldorf Steiner approach. The statement that "we also went and had weekends" positions the teachers as professionals who were happy to dedicate their free time to further develop their artistic knowledge. Teachers are positioned as a group of people who value art and were keen to engage in a range of relevant activities at every opportunity. The significance of teachers engaging with art themselves during training was discussed within the wider data set. The quote from Patricia below further explores this. 
"We went one month on an island and that was the most beautiful way of finding out, erm, what art is all about. Because we did movement, we did painting, we did drawing, we did music, we wrote, erm, we wrote something it would come out in any art form. That was, for me, the most, erm, the deepest experience I could have."

'Patricia'

Patricia draws upon her training experience to demonstrate the importance of "finding out what art is all about". Listing is used to illustrate the diverse range of artistic activities that her training exposed her to and thus positions art as an aspect of creativity that is not subject or form specific Use of this list also serves to present the teacher as someone who was fully immersed in artistic activity. This again illustrates the importance of art within Waldorf Steiner training as a whole month is spent on an island engaged in artistic activity both for training and pleasure. The training is construed as "beautiful" and "deep" which presents Patricia's time on the island as special and the training as an experience that enabled her to connect with art in a meaningful way. Patricia is positioned as a teacher who is experienced, knowledgeable and passionate about art. This further suggests that art is a site for a personal connection and reinforces the presentation of art as a topic that has deep significance and meaning. 
When discussing their experiences and training, teachers emphasised the value of art. Within these discussions the Waldolf Steiner philosophy of educating the 'whole child' and nourishing the head, heart and hands was evident.

"I loved it always I think, since I was a child I always wanted to and I sometimes just paint for fun when I feel, you know, I love colours." 'Patricia'

Repeated use of the word "always" maximises Patricia's involvement in art by presenting a life-long connection with the subject. Her suggestion that "I always wanted to" positions Patricia as someone who had an intrinsic motivation to engage with art activities "for fun". Patricia is positioned as a teaching professional who has first-hand experience of the benefits of art and understands its value. This potentially has implications for her teaching practice as Patricia is able to draw upon her personal experience to demonstrate her relationship and understanding of art to the pupils she teaches.

"I did loads of workshops teaching different art subjects in the summertime and all the children would come year after year after year after year because they need it so much. It feeds you, it gives you something to your soul, it just makes you. I don't know, it makes you know yourself better, understand who you are, discover, actually yourself." 'Patricia' 
Patricia goes on to discuss the value art has for the children she teaches and wider society. In the first part of the quote Patricia positions herself as an expert who gives children the opportunity to regularly engage with art through "loads of workshops". The frequency and significance of these workshops is stressed by her repeated use of "year after year". Art is conceptualised as an ever present part of the children's learning experience, something that they returned to willingly during their time at the school. Significantly, art is construed as a fundamental part of the child's education and personal development; something that the children "need". The need for art is further discussed and likened to food for the soul. Use of the word soul is significant as it points towards the spiritual benefits of engaging in art activities. This constructs art as a nourishing activity that has profound benefits for general well-being. At this point Patricia repeatedly uses the generic term "you" and this widens out the value of art beyond the children she teaches and suggests that it a fundamental part of everyone's existence as it is a tool which helps people to "understand who you are, discover, actually yourself". Art is presented as more than just a subject at school - it is part of our existence, self-discovery and fulfilment.

This section of the analysis has illustrated the ways in which Waldorf Steiner training and teacher's own involvement in art adequately prepared them to teach this subject effectively. Specialist training which offered the teachers the chance to engage with art in a meaningful way and develop their skills 
and relationship with art was construed as an essential element of good training. Teachers also stressed the value that they placed on art, this positioned them as passionate advocates of art who had the practical experience required to adopt the teaching position of expert both in terms of how art can be produced and understood. The analysis now moves on to consider how teacher's training and experience shapes their approach to art in the classroom and the opportunities this creates for children.

\section{Teacher and child's approach to art}

Within the interviews teachers stressed the importance of facilitating discussion in the class about art and also taking a very directive approach when teaching artistic skills. These practices were presented as essential ingredients for children's enjoyment of art.

\section{Class discussion}

The teachers agreed the classroom discussion was important but this discussion was used to achieve different functions and not always approached in the same way. This section of the analysis explores the function of class discussion and the different teaching positions adopted during discussion.

"You put them all on the wall and you can look at them and you can see absolutely all the works on the wall and you can help each child until the child feels proud of his or her work - which I also think is very important - to be happy with what you have done and then, erm, you can see them 
around, you can look, let's say in which, in which painting or drawing the yellow is more shining? Which painting or drawing; it is, I don't know, evening or morning, you know, where is the strongest or the brightest red or, you use a lot of the quality of the colours." 'Jane' Jane explains how discussion is initiated in her class by putting "absolutely all the works on the wall". This emphasises the inclusiveness of the classroom by indicating that every child has their work displayed and the teacher does not just choose good examples. Every child's art is valued and considered to be worthy of class discussion. The display and discussion of art is constructed as having two roles. First, it enables the children to "feel proud of his or her work". This link between creating art and feeling proud presents art as an activity which develops children's confidence and feelings of self-worth. Second, it allows the teacher to work with the children to develop their understanding of art. When guiding the discussion the teacher is positioned as an expert, someone who draws upon their knowledge to "help each child". As before, inclusivity is stressed as the teacher is presented as someone who works with every child to improve their relationship and confidence in art.

In the second part of the extract the teacher's position shifts to philosopher as she lists the types of questions used to illicit discussion. Here, it is important to note the different types of questioning used. Questions such as "where is the strongest or brightest red?" is one of an enquiring nature to discover what the children's opinion is. This is in stark contrast to questions 
such as "which painting looks most like a daffodil?" which gives the impression that there is a right or wrong way to do art based on how realistic the image is. This offers the children the opportunity to explore expression and realism in the artwork they are considering. The integration of working with the children to develop a relationship with art, prompting positive feelings and the position of philosopher is noteworthy. It presents art as more than just an academic topic in which students develop their aesthetic sensibilities - it is a space for personal growth.

"So we would put paintings around the room and say "oh where does the yellow really shining?" You know, and maybe in that one there, you know, "where's the blue looking a bit shy?" "Where's the blue stronger?" So they start to begin to be a bit discerning." 'Jessica'

Jessica describes the same scenario but highlights the use of probing questions and their role in developing children's appreciation and understanding of art. Repeated use of questions that start with "where's the..." invite the children to consider the quality of the colour, the emotion expressed by the colour and the strength of the colour. This line of questioning encourages the children to consider the formal properties of colour as well as the expressive function of colour. Consistent use of open ended questions requires the children to find the answers within themselves. This establishes different power dynamics as the teacher does not adopt the position of expert. Instead, she adopts more of a facilitator 
role in which she steps back and gives children the freedom to answer questions based on their own art values. This combination of facilitator and philosopher enables the children to play a more dynamic role in the lessons and express their views and opinions.

"I'd put a big piece of drawing paper up on the board and get my blocks and sticks out and then we'd say right okay, so, so we'd try and bring it out of the colour. So what are we going to put around? How are we going to form it?" 'Jessica'

Within the interviews, class discussion was not just confined to work completed by the children. Jessica describes how she uses questions to initiate discussion that will guide the creation of art.

Consistent use of the word "we" throughout the excerpt disrupts traditional classroom power relations and suggests that the teacher and children will work collaboratively. As in the previous extract the teacher simultaneously adopts the position of facilitator and philosopher. As a facilitator Jane offers the children freedom to play an active role in the lesson and this signals that their opinions are valid and just as important as the teacher's. As a philosopher Jane uses questions relating to "colour" and "form" to prompt the children to consider how formal properties can be used with different effects. 


\section{Painting is heavily guided}

Throughout the interviews the teachers stressed the importance of adopting the expert position and taking a very directive approach when demonstrating painting. This is illustrated below by Patricia.

"I always say we do it all, it's all directed, at the blackboard. So I always show and I say and then they all do it and I wait for them to do it and then I go with the next colour."

'Patricia'

Repeated use of the word "I" in this quote positions Patricia as central to the lesson. This suggests that without her expert knowledge and guidance the painting would not be completed correctly and the lesson would not fulfil its purpose. When describing her approach Patricia outlines how she demonstrates each step in the process and then "waits" for the children to copy.

On the one hand this emphasises the control she has over the class and reinforces traditional power dynamics in which children are placed in a passive position that requires them to carefully follow instruction. However, her suggestion that she "waits" indicates a level of sensitivity to the class and their needs as she works in time with the children. By suiting her pace to the children's needs and moving on when the children have "all" completed each step the teacher and the children are presented as a team working together to achieve a shared goal. 
The adoption of an expert teaching position and a highly directive approach could be seen as a barrier to children's creativity. Within the interviews the teachers defended this teaching approach and explored its benefits.

"I had an interesting experience with my own son, erm, because he'd done two years in mainstream school before he came here and he was only six when he came here and he said very early on "at my old school, erm, they didn't think very much of painting so were allowed to paint what you like but here you aren't allowed to paint what you like. You have to paint the colours as Nick tells us." you know. So that's quite interesting. Really I thought, that he'd-even thought it might seem less creative because he wasn't being allowed to do what he liked, he got the impression that it was being taken much more seriously."

'Jessica'

Jessica contrasts National Curriculum and Waldorf Steiner approaches to illustrate the importance of the expert teaching position and a focus on skills development. Jessica draws upon her son's experience and uses active voicing to construct National Curriculum art lessons as a space where teachers exclusively adopted the facilitator position and children were allowed to paint "what you like". This approach is construed as evidence that the National Curriculum schools do not "think very much of painting". There is the suggestion that the teacher's lack of active involvement in lessons was conceptualised as devaluing the subject. In contrast, the 
Waldorf Steiner approach is aligned with a lack of freedom and a requirement "to paint the colours as Nick tells us". Jessica suggests that this demonstrates that art is "taken much more seriously". The comparison between the two approaches defends the expert position adopted by Waldorf Steiner and presents it as the superior teaching approach. Jessica's assertion that her son noticed this "very early on" maximises the difference between the approaches and adds power to her narrative. It suggests that as a recipient of art education her son was aware of the difference and this adds a sense of authenticity to the claims made in her account.

"I mean people see this as very prescribed, but actually when you look at their paintings, and put them up on the wall, they never look the same. And actually for a child there's so much possibility and so much variation and so much of their character, their artistic thoughts are expressed even, you know, in a contained, $\mathrm{hm}$, lesson."

'Jane'

Jane draws upon her teaching experience to explain how, even within such a "prescribed" lesson, children can express themselves creatively through art. The statement that "they never look the same" uses an extreme case (never) to maximise the children's personal agency and ability to create unique art. This is further emphasised in the assertion that there is "so much variation" and "so much of their character" in the artwork. This works to position the artwork as a unique expression of each child's personality and not a direct copy of the teacher's demonstration. 
Therefore, a directive approach which emphasises skills is positioned as an essential element of creative expression. This construes the Waldorf Steiner approach as the best way by suggesting that within a "contained" lesson there are no limitations of what the children can learn.

\section{Children Enjoy Art}

All of the teachers suggested that children enjoy art. This theme investigates how their approach nurtured and developed this enjoyment.

"Well, well I mean the children are naturally so keen on their art work that they will, you know, so, I mean I would always well, assess, or give feedback on artistic work at the end of every main lesson." 'Jessica'

Jessica makes connections between child's "natural" interest in art and her teaching practices to position herself as a professional who instinctively responds to children's needs. Her practice of "giving feedback" is construed as a response to children's "keen" feelings towards the artwork they have created. Her feedback is construed as significant because it sends the message to the children that they have created something of merit that deserves special attention from the teacher. Her assertion that feedback is offered at "at the end of every main lesson" highlights the consistency of an approach that rewards the children's artistic efforts and reinforces the message that art is important. 
"So they are very pleased and proud of their work ... I was always really surprised, actually, that they are really in their work very deeply and they are very, erm, I don't know, they love it and to be honest I think their work of art is quite outstanding, how you can see on the walls. I think it's really beautiful, really beautiful"

'Patricia'

Patricia suggests that the children in her class have a positive relationship with art. An emotional connection with art is constructed as Patricia suggests that "They are very pleased and proud of their work" and is a topic they "love". This implies that art gives children the chance to feel good about themselves and what they have achieved. The children are also positioned as competent artists who "work very deeply" and create "quite outstanding" artwork. This suggests that the Waldorf Steiner approach enables children to develop their artistic skills and a positive emotional connection with art.

\section{Discussion}

This analysis has explored teachers' experiences of Waldorf Steiner training and how this informs their approach to art. In line with the aims and scope of qualitative methods the findings presented from this small scale, exploratory study cannot be generalised to the wider teaching population. However, the analysis has raised someimportant issues relating to teacher 
training and practice which warrant further consideration and exploration. Of primary interest to National Curriculum teachers may be the emphasis that Waldorf Steiner educators place on art as more than just an individual curriculum subject but rather a way of 'thinking, feeling and doing,' i.e. an integrated learning mechanism (Nichol, 2011). Art is positioned not just as a skills-based subject, but also as an outlet to develop pupils' confidence, sense of self, motivation, and well-being. This reflects the wider Waldorf Steiner ethos of educating the whole child based upon their own individual, developmentally appropriate needs (Edmunds, 2004), as well as the emphasis upon learning through the imagination to encourage flexible, divergent thinking.

The analysis also examined the importance of adequate training in art. Teachers spoke very positively about the art training they received and highlighted the opportunities to engage with art activities within the Waldorf Steiner approach. There is little published information about the specific art content of Waldorf Steiner training. Whilst this requires further research, the results of the current study imply that the teachers left their training confident in their skills as an artist and with first hand experiences of the benefits of art. Consequently, the teachers could be positioned as good role models in the classroom who were able to demonstrate to the class that adults engage with art and therefore it is an important topic that has lifelong benefits. This stands in stark contrast to research that suggests that National Curriculum training does not prioritise art and therefore teachers are not adequately prepared to teach art with knowledge and confidence 
(Clement, 1994; O'Connor, 2000; Neelands et al., 2015). Superior expressive art ability within children educated within the Waldorf Steiner system could be explained by their teacher's preparedness to approach the subject from a position of expert knowledge.

Important differences between National Curriculum and Waldorf Steiner teaching practice were also evidenced in the analysis. When discussing their teaching practice the teachers presented a blended approach which incorporated the positions of expert, philosopher and to a lesser degree facilitator. Class discussion was presented as a space in which the philosopher position was adopted. Within these discussions some teachers combined expert and philosopher positions in order to take an active role in guiding the discussions whereas others combined facilitator and philosopher positions to enable the children a more active role. Contrary to National Curriculum practice, this suggests that Waldorf Steiner teachers spend more time discussing issues relating to aesthetics and art understanding with their pupils. Aesthetic factors have long been of interest to scholars and motivate human behavior by providing positive affective and cognitive experiences (Leder et al., 2004). Research into children's aesthetic appreciation is limited (Lin \& Thomas, 2002) therefore a study of how Waldorf Steiner practices affect aesthetic development would constitute an important contribution to this field.

In comparison to discussing their practice, the current study suggests that when teaching art, Waldorf Steiner teachers exclusively adopted an expert 
position to (i) provide the children with the skills needed for self-expression and (ii) demonstrate that they value art and take it seriously. One means through which teachers directed children's art learning was through modeling (e.g., demonstrating the formal use of colour). The use of modelling within Western art education has traditionally been discouraged for fear that it will inhibit creativity (Braswell, 2006). However, consistent with the superior expressive drawing skills of Waldorf Steiner pupils it is possible that such models provide children with the graphic skills necessary to draw realistically, which can then be implemented and modified in the production of imaginative and creative images. In support of this argument, a foundation in direct skills-based art instruction has also been posited as one reason for the more advanced expressive drawing skills of Chinese children compared to their British counterparts (Winner, 1989; Jolley, 2010). Within the interviews there was little evidence of the facilitator position being formally adopted in art lessons. This could be considered a limitation of the Waldorf Steiner approach as children are given little opportunity for free expression. However, the teachers argued that emphasis on the expert and philosopher positions were key to enabling children the opportunity to develop a good relationship with art and positive feelings towards artistic ability. Indeed, teachers reported that their pupils valued art and took pride in their work. This is consistent with reports that Waldorf Steiner teachers are instructed to focus upon the process rather than outcomes of children's artistic endeavours, and to avoid judgment or comparison between individuals (Nichol, 2011). From a pedagogic perspective, a focus upon the 'how' rather than the 'what' of art should facilitate a deep rather than 
surface or strategic approach to learning (Anderson \& Krathwohl, 2001) which is associated with higher levels of intrinsic motivation, confidence and a genuine love for the subject matter (Sivan, Wong Leung, Woon \& Kember, 2000). However, as previous research demonstrates, such an art approach can be difficult to incorporate in National Curriculum schools where there is a cultural emphasis upon individual performance outcomes and rank ordering of ability (Hall, Thomson \& Russell, 2007).

The way that Waldorf Steiner teachers adopted different teaching roles to suit the activity they were engaged with also indicates that their curriculum and training gives them the freedom to do this. Whilst further research is needed to identify what specific aspects of training enable this, it contrasts greatly with National Curriculum teachers' reports relating to dissatisfaction with the curriculum and an inconsistent teaching approach that favours the expert or facilitator position (Hallam et al. 2008; Hallam et al 2011). This may be compounded by a recent decline in hours dedicated to art teaching within the National Curriculum, and a decrease in the number of pupils choosing to pursue art at GCSE and A level (Neelands et al, 2015). Such differences suggest that the superior expressive drawing development evidenced in Waldorf Steiner children could in part be explained by exposure to teachers who have been trained in an educational philosophy which prioritised art and emphasised the importance of teachers experiencing the subject themselves. This is supported by cultural learning theories (e.g., Callaghan, 1999) which assert that drawings are produced in a shared social context where more experienced others provide graphic models with which the child can scaffold their own productions (Wilson \& 
Wilson, 1985). Pariser, Kindler and Van Den Berg (2008) assert that because such models and preferred artistic practices differ between contexts, graphic development is likely to follow multiple pathways (rather than a single linear one), which are characterised by the particular values of that culture. In Waldorf Steiner education, this pathway appears to be an advanced and beneficial one. Differences between the drawing abilities of those in Waldorf Steiner and other educations systems could also relate to a consistent teaching approach which prioritises the positions of philosopher and expert. Evidence from the interviews suggests that these teaching positions work together to send a strong message to children that art is important and the artwork they create is of clear value.

. To summarise, this analysis has revealed the high status that is accorded to art and arts based teacher training within the Waldorf Steiner approach, as well as the provision of expert, skill specific instruction that focuses upon the process (as well as product) of artistic activity. As research suggests that art teaching is an area of vulnerability for national curriculum teachers (O'Connor, 2000) it is possible that the results discussed here could suggest a model for changes in training and teaching practice. Specifically, increasing the amount of training as well as direct experience with art could help prepare teachers to approach the topic with a sense of knowledge and confidence and support them in adopting a balanced teaching approach that incorporates the position of philosopher. This suggestion is timely, as recent research suggests an $11 \%$ decline in the number of art specialists teaching in state schools since 2010, suggesting a trend towards the increasingly general nature of art provision (Neelands et al, 2015). 
In addition, central to the Waldorf Steiner approach is the use of art as a holistic, healing activity which helps to balance the well-being of the individual (Nichol, 2011). This mirrors inductive educational approaches in Scandinavia which use art as a means to facilitate children's personal, social and moral development (e.g., Kroflic, 2012; Nevanen, Juvonen, Ruismaki, 2014) and $\mathrm{h}$ could potentially benefit British mainstream education where interventions relating to the mental health of both staff and pupils are increasingly being considered (Kyriacou, 2001; Ludwig, Lyon \& Ryan, 2015). However, it is important to remember that the findings presented in this paper are based on a specific school and therefore cannot easily be generalised. As the school had academy status it is also possible that OFSTED inspections may have subtly influenced pedagogy and practice in comparison to fully independent Waldorf Steiner schools. Despite this limitation the reported findings point towards important differences between Waldorf Steiner and National Curriculum approaches that warrant further investigation. Future research could analyse the arts based content of Waldorf Steiner teacher training and use observational methods to investigate whether this content and teacher's reports of teaching practice map on to the reality of the classroom experience (Sobo, 2014).

\section{References}


Anderson, L. W., \& Krathwohl, D. R. (eds.) (2001). A taxonomy for learning, teaching, and assessing: A revision of Bloom's taxonomy of educational objectives. New York: Longman.

Barnes, H. (1991). Learning that grows with the Learner: An introduction to Steiner Education. Educational Leadership. Retrieved from:

http://www.sonoma.edu/users/f/filp/libs_200/waldorf.pdf

Braswell, G. S. (2006). Socio-cultural contexts for the early development of semiotic production. Psychological Bulletin, 132 (6), 877-894.

Braun, V. \& Clarke, V. (2006). Using Thematic Analysis in Psychology.

Qualitative Research in Psychology, 3(2), pp. 77-101

Burkitt, E., Jolley, R. P., \& Rose, S.E. (2010). The Attitudes and Practices that Shape Children's

Drawing Experience at Home and at School. International Journal of Art and Design Education, 25(3), 341- 349.

Burr, V. (1995). Introduction to social constructionism. London, UK:

Routledge.

Clement, R. (1994). The readiness of primary schools to teach the National Curriculum in Art and Design. Journal of Art and Design Education, 13(1), 919.

Cherney, I. D., Seiwert, C. S., Dickey, T. M., \& Flichtbeil, J. D. (2006).

Children's drawings: A mirror to their minds. Educational Psychology, 26 (1), 127-142. 
Cox, M.V., \& Rowlands, A. (2000). The effect of three different educational approaches on children's drawing ability: Steiner, Montessori and traditional. British Journal of Educational Psychology, 70, 485-503.

Davis, J. (1997). Drawings Demise: U shaped Development in Graphic Symbolization. Studies in Art Education,38, pp. 132-157.

Davis, J. (2005). Framing education as art: The octopus has a good day. New York: Teachers College Press.

Department for Education (2013). National Curriculum in England: Art and design programmes of study. Retrieved from https://www.gov.uk/government/publications/national-curriculum-inengland-art-and-design-programmes-of-study

Edmunds, F. (2004). An introduction to Steiner education: The Waldorf School. Sophia Books: Rudolf Steiner Press.

Frith, H. \& Gleeson, K. (2004). Clothing and embodiment: men managing body image and appearance. Psychology of Men and Masculinity, 5(1), pp. 40-48.

Hall, C., Thompson, P., \& Russell, L. (2007). Teaching like an artist: the pedagogic identities and practices of artists in schools. British Journal of 
Sociology of Education, 28 (5), 605-619. DOI:

$10.1080 / 01425690701505466$.

Hallam, J. L., Das Gupta, M., \& Lee, H. (2008). An exploration of primary school teachers' understanding of art and the place of art in the primary school curriculum. Curriculum Journal, 19(4), 269-281.

Hallam, J. L., Das Gupta, M., \& Lee, H. (2011). Shaping children's artwork in English primary classes: Insights from teacher-child interaction during art activities. International Journal of Early Years Education, 19(3-4), 193-205. doi:10.1080/09669760.2011.629489

Hallam, J. L., Lee, H. A. N., \& Das Gupta, M. (2012). Multiple interpretations of child art-the importance of context and perspective. Psychology of Aesthetics, Creativity, and the Arts, 6(2), pp. 185-193. doi:

$10.1037 / \mathrm{a} 0025793$

Hallam, J. L., Lee, H., \& Das Gupta, M. (2011). An investigation into the ways in which art is taught in English reception classes. Psychology of Aesthetics, Creativity, and the Arts, 5(2), pp. 177-185.

Hallam, J. L., Lee, H., \& Das Gupta, M. (2007). An analysis of the presentation of art in the British primary school curriculum and its 
implications for teaching. International Journal of Art and Design Education, 26(2), pp. 206-214.

Hetland, L., \& Winner, E. (2004). Cognitive transfer from art education to non arts outcomes: Research evidence and policy implications. In E. W. D. Eisner, M. D. Day (Ed.), Handbook of research and policy in art education. USA: New Jersey: Laurence Erlbaum Associates pp. 135-162.

Jolley, R. P. (2010). Children and pictures: Drawing and understanding. UK, Oxford: Wiley Blackwell.

Jolley, R. P., Fenn, K., \& Jones, L. (2004). The development of children's expressive drawing. British Journal of Developmental Psychology, 22, pp. 545-567.

Kirkham, J. A., \& Kidd, E. (2015). The effect of Steiner, Montessori and National Curriculum education upon children's pretence and creativity. The Journal of Creative Behaviour. Vol. 0, Iss. 0, pp. 1-20. DOI: 10.1002/jocb.83|

Kroflic, R. (2012). The role of artistic experiences in the comprehensive inductive educational approach. Pastoral Care in Education: An International Journal of Personal, Social and Emotional Development. 30 (3), 263-280.

DOI: $10.1080 / 02643944.2012 .671342$ 
Kyriacou, C. (2001). Teacher stress: Directions for future research.

Educational Review, 53:1, 27-35, DOI: 10.1080/00131910120033628.

Leder, H., Belke, B., Oeberst, A., \& Augustin, D. (2004). A model of aesthetic appreciation and aesthetic judgments. British Journal of Psychology, 95, 489-508. doi:10.1348/0007126042369811

Lee, H.A.N. (2002.) An ethic of involvement in researching spirituality. Feminism and Psychology vol. 15(4)

Lim, B. (2004). Aesthetic discourses in early childhood settings: Dewey, Steiner and Vygotsky. Early Child Development and Care, 174 (5), 473-486.

Lin, S. F., \& Thomas, G. V. Development of understanding of popular graphic art: A study of everyday aesthetics in children, adolescents and young adults. International Journal of Behavioral Development, 26 (3), 278-287.

Ludwig, K, A., Lyon, A, R., \& Ryan, J. L. (2015) Anxiety in youth: Assessment, treatment, and school based delivery. In R. Flanagan, K. Allen., \& E, Levine (Eds). Cognitive Behavioral Interventions in the Schools: Integrating Theory and Practice (pp 45-65). New York: Springer..

Mies, M. (1993). Towards a methodology for feminist research. Chapter in M. Hammersley (Ed). Social Research: Philosophy, Politics and Practice. London: Sage. 
Neelands, J., Belfiore, E., Firth, C., Hart, N., Perrin, L., Brock, S., Holdaway, D \& Woddis, J. (2015). Enriching Britain: Culture, Creativity and Growth. The 2015 Report by the Warwick Commission on the Future of Cultural Value. Coventry: The University of Warwick.

Nevanen, S., Juvonen, A, Ruismaki, H. (2014). Does arts education develop school readiness? Teachers' and artists' points of view on an art education project. Arts Education Policy Review, 115, 72-81.

DOI:10.1080/10632913.2014.913970

Nicol, J. (2011). Doing is learning: The domestic arts and artistic activities. In R. Parker-Rees (Ed.), Meeting the child in the Steiner kindergartens: An exploration of beliefs, values and practices. (pp.68-80). London, United Kingdom: Routledge.

O'Connor, M. (2000). The Creative Tension which Stifles Children. The Independent Supplement.18 ${ }^{\text {th }}$ May, 8-9. Cited in Rowlands, A., \& Cox, M. (2001). Steiner Education and Young Artists: A Comparison of Drawing Ability in Steiner, Montessori and Traditional Schools. Paideo. A Research Journal For Waldorf Education. Dec No. 24.

Ogletree, E. J. (2000). Creative thinking development of Waldorf school students. Trans Intelligence Magazine, 8. 
Pariser, D. A., Kindler, A. M., \& Van Den Berg, A. (2008). Drawing and aesthetic judgements across different cultures: Diverse pathways to graphic development. In C. Milbrath \& H. M. Trautner(Eds.,) Children's understanding and production of pictures, drawings and art: Theoretical and empirical approaches (pp. 293-318). Hogrefe \& Huber Publishers.

Parsons, M. J. (1987). How We Understand Art: A Cognitive Developmental Account of Aesthetic Experience. Cambridge, UK: Cambridge University Press.

Pitman, G. (2002). Outsider/insider: The politics of shifting identities in the research process.

Feminism and Psychology. Vol. 12(2) pp. 282-288.

Rose, S. E., Jolley, R.P., \& Charman, A. (2012). An investigation of the Expressive and Representational Drawing Development in National Curriculum, Steiner and Montessori School. Psychology of Aesthetics, Creativity and the Arts, 6(1), 83-95.

Sivan, A., Wong Leung, R., Woon, C \& Kember, D. (2000). An implementation of active learning and its effect on the quality of student learning. Innovations in Education and Training International, 37: 4, 381-389. DOI:10.1080/135580000750052991. 
Sobo, E. J. (2014). Play's relation to health and well-being in preschool and kindergarten: Waldorf (Steiner) education perspective. International Journal of Play, DOI: 10.1080/21594937.2014.886102

Steiner Waldorf Schools Fellowship. (2014). Retrieved from http://www.steinerwaldorf.org

Toerien, M. (2004). Hair removal and the construction of gender. A multi method approach. PhD Thesis: York.

Urban, K. K., \& Jellen, H. G. (1996). Test for Creative Thinking - Drawing Production (TCT-DP). Lisse, Netherlands: Swets \& Zeitlinger.

Vail, D. (1999). Researching from afar. Distance ethnography, and testing the edge. Journal of Contemporary Ethnography. Vol 30(6) pp. 704- 725.

Vessel, E.A., \& Rubin, N.(2010). Beauty and the beholder: highly individual taste for abstract, but not real-world images. Journal of Vision. 10 (2), 1- 14.

Vygotsky, L. (1978). Mind in society: The development of higher psychological processes. Cambridge, MA: Harvard University Press.

Wildgruber, T. (2012). Painting and Drawing in Waldorf Schools: Classes 1 to 8. Edinburgh: FlorisBooks. 
Wilson, B., \& Wilson, M. (1977). An iconoclastic view of the imagery sources in the drawings of young people. Art Education, 30, 4-12.

Winner, E. (1989). How can Chinese children draw so well? Journal of Aesthetic Education, 41-63.

Yagamata, K. (1997). Representational activity during mother-child interactions: The scribbling stage of drawing. British Journal of Developmental Psychology: 15, 355-366. 
*Highlights (for review)

\section{Highlights}

Children who are educated using a Waldorf Steiner approach demonstrate superior expressive drawing skills but little is known about this teaching approach

Teachers trained in the Waldorf Steiner approach reported that they had adequate art training and believed in the value of art

When teaching art they focused on both teaching the topic and enabling children to develop their feelings of self-worth and confidence

Children educated within a Waldorf Steiner approach receive an education that focuses on the head, heart and hands 
